Agenda

\title{
$S$ v Mthethwa: Justice for sex workers in the face of criminalisation?
}

\section{Cherith Sanger}

To cite this article: Cherith Sanger (2020) S v Mthethwa: Justice for sex workers in the face of criminalisation?, Agenda, 34:1, 117-123, DOI: 10.1080/10130950.2019.1692514

To link to this article: https://doi.org/10.1080/10130950.2019.1692514

册 Published online: 07 Feb 2020.

Submit your article to this journal $\pi$

Џlll Article views: 118

Q View related articles $₫$

View Crossmark data $\nearrow$ 


\title{
$S$ v Mthethwa: Justice for sex workers in the face of criminalisation?
}

\author{
Cherith Sanger
}

\section{abstract}

In 2017 the Western Cape High Court convicted acclaimed painter, Zwelethu Mthethwa, of the brutal murder of sex worker, Nokuphila Khumalo. This profile offers a feminist-legal analysis of the judgment and sentence handed down by Judge Patricia Goliath. Essentially, it explores the various inequalities between Khumalo and Mthethwa and its impact on Khumalo's vulnerability to violence. The author argues that Khumalo's dichotomous and disadvantageous position to Mthethwa, due to her sex, gender, the criminalised status of her work and her socioeconomic status, enabled the brutal and fatal attack which Mthethwa perpetrated against her. Ultimately, it is argued that Khumalo's murder was a consequence of her 'low' status in society, based on the various grounds of vulnerability and inequality that enabled her murder. The judgment and sentence provided a sense of justice for Khumalo, her surviving family members and all other sex workers in South Africa; however, true and meaningful justice cannot be delivered under the criminalisation of sex work. It is further concluded that to some extent, the judgment and sentence has 'humanised' sex workers by sending the message to society that sex workers have the right to have their human dignity, equality and freedom respected, protected and fulfilled.

\section{keywords}

human rights, inequality, justice, sex work, socio-economic status, violence, women

\section{Defining sex work}

Sex work is the provision of 'sex for reward'. It involves the provision of labour or services of a sexual nature, including sex or acts of sexuality, in exchange for a negotiated reward. Such reward can be monetary or in kind (Sanger, 2015; Lakhani, 2015). Sex work is often still referred to as 'prostitution'. This term perpetuates negative stereotypes and stigma about sex workers. It shows disrespect for the dignity of sex workers and constitutes offensive language which shames them. In contrast, the terminology 'sex work' inherently recognises that sex work is a form of work. It thus neutralises adverse assumptions and oppressive opinions about sex workers. Accordingly, the terminology 'sex work' is used throughout this profile.

\section{The criminalisation of sex work}

Sex work is fully criminalised in South Africa. The Sexual Offences Act 23 of 1957 and the Criminal Law (Sexual Offences and Related Matters) Amendment Act 32 of 2007 collectively criminalise the

This article has been republished with minor changes. These changes do not impact the academic content of the article. 


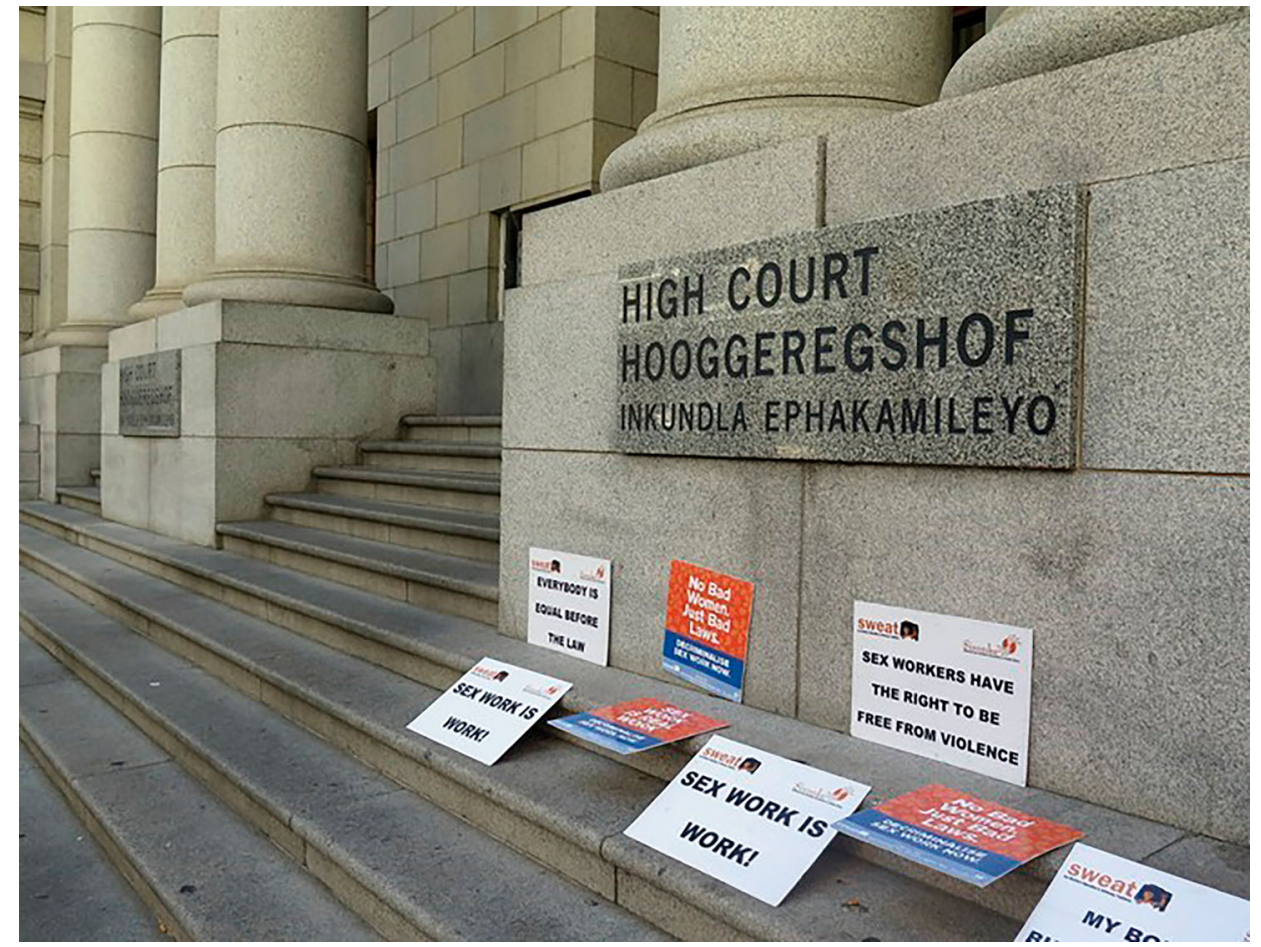

Placards outside the High Court during Zwelethu Mthethwa's trial. Photo: GroundUp, Ashleigh Furlong (CC BY-ND 4.0).

buying and selling of sex by consenting adults. Both statutes also criminalise associated activities such as brothelkeeping, and living off the proceeds of sex work. Furthermore, the Businesses Act 71 of 1991 and the Riotous Assemblies Act 17 of 1956 contribute to the overall criminalisation of the sex industry. The Businesses Act requires that all businesses are licenced to practice and only those providing lawful services are permitted to operate. Accordingly, the Act criminalises brothels falsely registered as a legitimate businesses. The Riotous Assemblies Act, among others, prohibits attempting to commit an offence, conspiring or inciting, aiding, instigating, commanding or procuring another person to engage in conduct which is prohibited under another law. Lastly, provincial level bylaws on soliciting, drunken behaviour and loitering are used indirectly to police sex workers, and to practically enforce criminalisation against sex workers, as less evidence is required for enforcing these by laws than charging sex workers under the 1957 and 2007 sexual offences legislation.

\section{Women, the criminalisation of sex work and human rights}

Sex work is criminalised under South African law despite the fact that our supreme Constitution obligates the State to respect, protect, promote and fulfil the rights in the Bill of Rights. Chapter 2 of the Constitution contains the Bill of Rights, which gives all people living in South Africa fundamental human rights. Some of these rights include the right to human dignity, equality, freedom and security of the person. Section 9 of the Bill of Rights provides that the State may not unfairly discriminate against persons on the grounds of sex and gender. The equality clause further obligates the State to "promote the achievement of equality" by taking legislative and other measures to "protect or advance persons" or groups of people "disadvantaged by unfair discrimination" (Republic of 


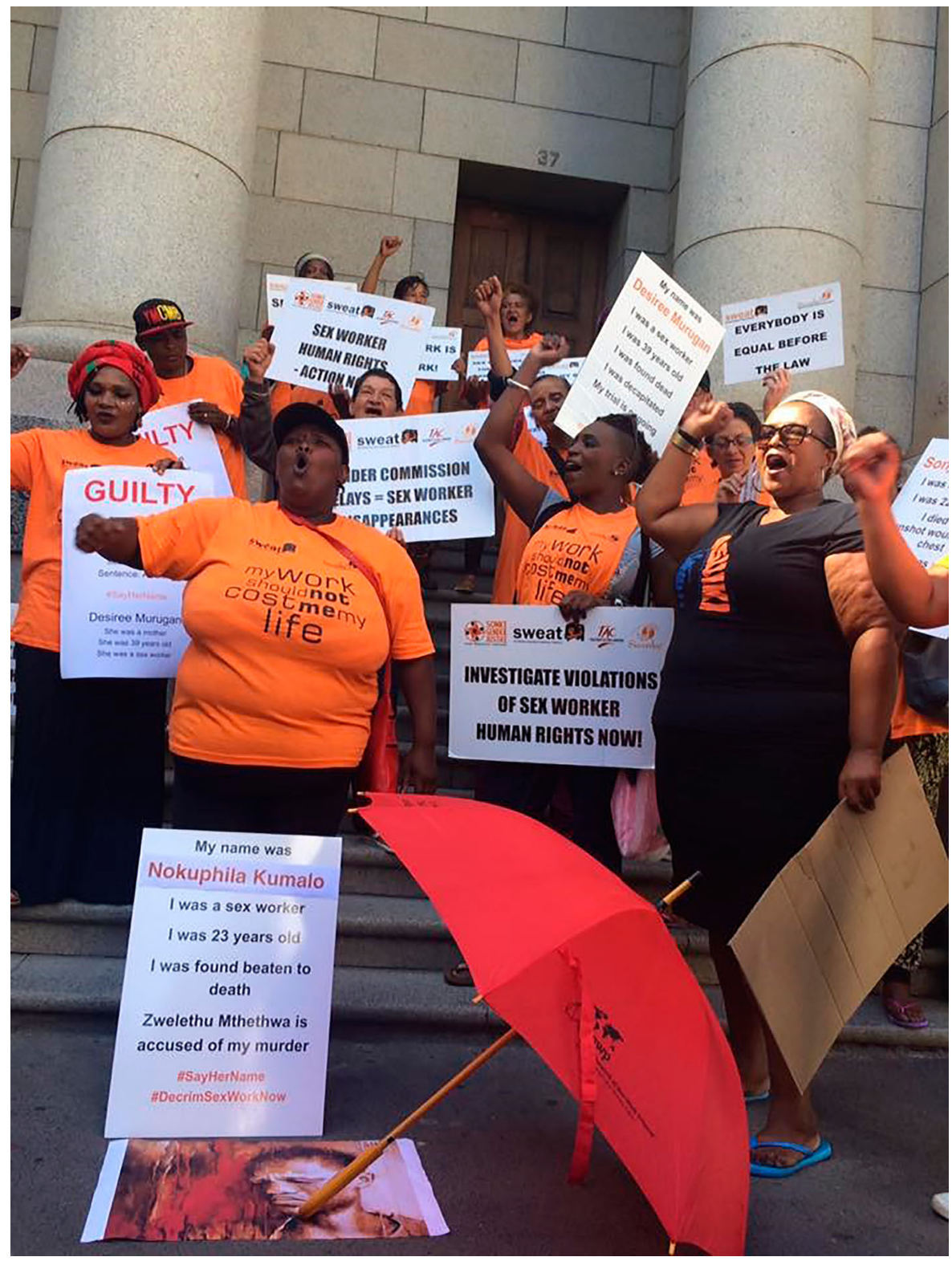

The Sex Workers Education and Advocacy Task Force (SWEAT) and Sisonke National Sex Worker Movement demonstrated outside the Western Cape High Court during Zwelethu Mthethwa's trial while calling for justice for Nokuphila Khumalo. Photo: Lesego Thwale of SWEAT

South Africa, 1996). Section 12 of the Bill of Rights is particularly significant for sex workers and for this profile, in that it gives sex workers the right to freedom and security of the person, which includes the right to be free from all forms of violence and not to be treated in a cruel, inhuman or degrading way. In addition, Section 23 of 
the Bill of Rights sets out the rights to freedom of trade, occupation and profession. Sex workers are, however, unable to enforce this right because it is limited by the State's right to regulate any such trade, occupation or profession. The latter entails that legislation criminalising sex work limits the right as contained in Section 23.

\section{Women, sex work and economic disadvantage}

As at April 2013, it was estimated that there were 182000 sex workers in South Africa. Approximately 167000 sex workers were female (Stacey et al, 2013). Accordingly, the vast majority of sex workers were female, and undoubtedly the majority of sex workers continue to be female.

Many people who work in illegitimate markets do so as a means of surviving economically (Newham and Faull, 2011). Sex workers are no exception. They use sex work as a means of income generation. Hendin's 2019 report states that "most sex workers in South Africa are poor, black, and female, and sell sex primarily in order to support their children, as well as other dependents." Hendin further reports that "[s]ex workers interviewed for... [its]... report described how poverty, lack of education and severely limited economic opportunities, ... made sex work one of the only viable options for supporting themselves and their families...". In addition, the study revealed that "[m]any [sex workers] were single mothers, often supporting children of siblings as well as their own ..." (Hendin, 2019).

\section{Sex work and vulnerability to violence under criminalisation}

Sex workers are a marginalised group of people, who are vulnerable to violence because of the criminalised and illegal status of their work (Lee and Reid, 2018). Hendin's 2019 report states that criminalisation " ... contributes to and reinforces stigma and discrimination against sex workers ...". Sex workers' vulnerability under criminalisation is exacerbated by criminal sanctions, because of the difficulty and fear they have of laying a criminal charge. By revealing their identities and coming forward to lay charges, sex workers both incriminate themselves and expose themselves to further discrimination and prosecution. Hendin's report (2019) further states that "[s]ex workers said that they were vulnerable because criminalisation forced them to work in or go to dark or dangerous spots and because criminals... knew they had bad relations with the police...".

Research from the United States suggests that female sex workers are 18 times more likely to be murdered than women of a similar age and race who do not work as sex workers (Potterat et al, 2004). In a study of sex workers in the United Kingdom, it was found that the mortality rate of female cisgender sex workers is 12 times higher than that of the general population, with the leading cause of death being murder (Ward and Weber, 1999). Lee and Reid (2018:51) are of the view that women are murdered because of a "misogynistic culture that views ... [them] ... as sex objects ..." who are ultimately the cause of their own deaths. Similarly, the United Nations Office of Drugs and Crime's global study on gender-related killing of women and girls concludes that "[t]he killing of female sex workers is... [an] example of the homicide of women in which attitudes of possessiveness and male superiority may play a role" (UNODC, 2018).

\section{S v Mthethwa: Case summary}

\section{Background}

On 16 March 2017, Judge Patricia Goliath ('Goliath $J$ ') found Mthethwa guilty of the murder of Khumalo. On 7 June 2017, she sentenced Mthethwa to 18 years' imprisonment. Khumalo was murdered at approximately 2.47 am on Sunday, 14 April 2013. Her death was the result of a brutal attack perpetrated against her by Mthethwa at Ravenscraig Road, Woodstock, Cape Town. The attack was carried out through a series of interrupted slaps, punches, kicks and stomps 'with a booted foot'. Khumalo's death was caused by a blunt force injury to her chest which resulted in both of her liver lobes being torn apart. The motive for the attack remains unknown, partially due to Mthethwa electing to not testify during the trial.

The brutality of the attack is clear from the evidence led by Dr Linda Liebenberg, 
the pathologist who conducted the postmortem on Khumalo's body, as well as from the closed-circuit television (CCTV) footage of the attack. In addition to the fatal liver injury, Dr Liebenberg found that Khumalo suffered blunt force injuries to the face, rib abrasions and crack fractures of the ribs. In relation to the CCTV footage, Goliath J described the attack as a "horrific incident which saw a young woman attacked in the most brutal manner". She further described Mthethwa as "display[ing] a great degree of anger towards the victim during the attack."

\section{The Judgment}

Even though Gulum Petersen, a state witness testified that Khumalo was a sex worker, neither the fact that Khumalo was a woman or sex worker played a role in Goliath J's judgment. The case was purely decided on criminal law principles and an assessment of the evidence put before the court. As with hate crimes committed against lesbian, gay, bisexual, transgender, intersex and queer persons, migrants, people living with HIV and other marginalised groups of people who experience unfair discrimination in South Africa, the South African Police Service records the incident as a crime without reference to the motive for the crime. Similarly, a criminal case is tried in accordance with the requirements of a criminal offence, which is not dependant on the vulnerability of the victim or the motives for the commission of the offence at the time that the accused is charged. Consequently, it is essential that the prosecutor in the criminal trial brings the motive to the attention of the court by eliciting evidence from witnesses that indicates that the crime was motivated by hatred or unfair discrimination against the victim. These factors do, however, play a critical role in sentencing.

\section{The sentence}

The 18 years' imprisonment sentence represents a harsher sentence than the 15-year custodial sentence prescribed for murder in terms of Section 51(2)(a) of the Criminal Law Amendment Act 105 of 1997. Goliath J reasoned that the decision to sentence Mthethwa to 18 years' imprisonment was made in an effort to deliver justice. She further justified the sentence by acknowledging that "violent crime against women" is rife in our society and that a severe sentence is warranted considering the interests of society in relation to the prevalence of the crime. The learned Judge further explained that the "aggravating features of the case... [were]... overwhelming". Such factors included considering that Mthethwa kicked Khumalo 60 times and paused between the kicking attacks, which meant that he had time to reflect on his actions but nonetheless continued his assault. In explaining her reasons for the sentence, Goliath J significantly made clear statements about Khumalo's status as a sex worker and the role that it played in her murder. Most importantly, she acknowledged that Khumalo's "vulnerability was exacerbated" on the grounds that she was a sex worker. She explained that the purpose of the sentence was to deter gender-based violence. She specifically stated that "[t]he killing of women in general will not be tolerated ... and that the killing of sex workers in particular, will not be tolerated." From a human rights perspective, Goliath J pointedly expressed that "[t]he accused conducted himself with flagrant disregard for the sanctity of human life." She was of the opinion that "[h]e acted in a manner that is unacceptable in any civilised society".

\section{Inequality as an enabler of Mthethwa's assault of Khumalo}

Inequality between Khumalo and Mthethwa is intrinsically linked to Mthethwa's brutal and fatal attack on Khumalo. This inequality is borne from Khumalo's sex, gender, the criminalised status of her work, and her economic disadvantage. (The author has knowledge of the economic circumstances of Khumalo due to her involvement in the case during her employ at SWEAT while the organisation was monitoring the case.) Khumalo and Mthethwa are dichotomous on the basis of their respective sex and gender, with Mthethwa benefitting from patriarchal dominance in South African society.

In addition, misogyny is prevalent in South African society, and this is evident from the high levels of gender-based violence perpetrated against women by men. In this profile, gender-based violence is 
taken to be "violence perpetrated against somebody based on their gender as a result of historical and cultural dimensions which inform and perpetuate stereotypical attitudes and behaviours within our society" (Sanger, 2015:15). The prevalence of gender-based violence is apparent from the National Department of Health's 2016 study, which revealed that 1 in 5 women over 18 years of age experience physical violence, and $6 \%$ experience sexual violence perpetrated by an intimate partner (National Department of Health et al, 2017). Further, it is evident from the $117 \%$ increase in femicide between 2015 and 2016/2017 that was reported by Statistics South Africa (2018).

The dichotomy between Khumalo and Mthethwa is also evident on the basis that Mthethwa possessed wealth and Khumalo worked as a sex worker to generate income, with little to no other income-generation opportunities. Mthethwa's economic advantage over Khumalo is proven by his ownership of a basalt black Porsche 911 Carrera Sport Z S vehicle at the time of the murder. The stigma that Khumalo faced from society as a sex worker and Mthethwa's status as an acclaimed, award-winning artist again illustrates a dichotomy from a social perspective. In addition, Mthethwa has formal education in the form of an undergraduate degree from a South African university and a master's degree from a university in the United States of America.

There was also an imbalance between the physical capabilities of Khumalo and Mthethwa, with Khumalo once again in a disadvantageous position. The court refers to Khumalo as a "petite young lady weighing merely $46 \mathrm{~kg}^{\prime \prime}$. In contrast, Mthethwa is at least $1.75 \mathrm{~m}$ tall, which is tall for a South African man (Businesstech, 2016). Khumalo's status as a sex worker, her sex, gender and socio-economic status all played a direct role in the attack which resulted in her death. It is submitted that but for Khumalo's inequality to Mthethwa, he would have been less likely to have launched the attack on her, and she would have been less likely to have been murdered. Khumalo's vulnerability to violence was acute, because her inequality was multilayered and intersectional in nature (Crenshaw, 1990).

Khumalo represented an easy target for violence, as her legal and socio-economic standing in the social hierarchy were 'low'.
Moreover, should Khumalo have survived the assault, the chances of her reporting it and receiving legal recourse were slim, considering how such a report to the South African Police Service would possibly draw attention to her involvement in the commission of sex work-related criminal offences.

\section{Conclusion}

The judgment and sentence represent some level of justice for Khumalo, her surviving family members, and all sex workers in South Africa. This conclusion is reached, accepting that justice cannot be fully realised for sex workers under the criminalisation of sex work. The only way to ensure justice for sex workers is through law reform of criminalisation. A reformed legal position must have the impact of eliminating stigma against sex workers, and allowing them to fully exercise and enforce their human rights and access to the courts for recourse in the face of human rights violations.

The essential aspects of the sentence lie in Goliath J's acknowledgement that Khumalo's grave experience of violence was accompanied by disrespect for her human dignity on the dual grounds of her gender and status as a sex worker. The sentence is significant for sex workers, in that is has 'humanised' sex workers by sending the message to society that sex workers deserve human dignity, and their human rights to freedom and equality must be fulfilled in the same way as they are for all other people living in South Africa.

\section{References}

Businesstech (2016) 'The world is getting taller - but not so much in South Africa', available at: https:// businesstech.co.za/news/general/131750/the-worldis-getting-taller-but-not-so-much-in-south-africa/, site accessed January 15, 2020.

Crenshaw, K (1990) 'Mapping the Margins: Intersectionality, Identity Politics, and Violence against Women of Colour', in Stanford Law Review, 43, 6, 1241-1299.

Hendin R (2019) 'Why Sex Work Should be Decriminalised in South Africa', available at: https://www.hrw.org/report/2019/08/07/why-sexwork-should-be-decriminalised-south-africa, site accessed September 4, 2019.

Lakhani I (2015) 'Position Paper on Sex Work in South Africa', available at: http://www.sweat.org.za/wpcontent/uploads/2016/02/Position-Paper-on-Sex- 
Work-in-South-Africa-2015-1.pdf, site accessed September 4, 2019.

Lee $\mathrm{J}$ and Reid S (2018) 'Serial killers and their easy prey', in Contexts, 17, 2, 46-51.

National Department of Health, Medical Research Council of South Africa and DHS Program ICF (2017) 'Demographic and Health Survey - Key Indicator Report', available at: https://www. statssa.gov.za/publications/Report\%2003-00-09/ Report\%2003-00-092016.pdf, site accessed September 4, 2019.

Newham, G and Faull A (2011) 'Protector or predator? Tackling police corruption in South Africa', in Institute for Security Studies Monographs, 182, 1-74.

Potterat J, Brewer D, Muth S, Rothenberg R, Woodhouse D, Muth J, Stites H and Brody S (2004) 'Mortality in a long-term open cohort of prostitute women', in American Journal of Epidemiology, 159, 8, 778-785.

Republic of South Africa (1996) The Constitution of the Republic of South Africa, 1996, available at: http:// www.justice.gov.za/legislation/constitution/SACo nstitution-web-eng.pdf, site accessed November 4, 2019.

Sanger C (2015) How to Support Community Members Affected by Gender Based Violence: A Guide for
Community Activists and Human Rights Defenders, Cape Town: Sonke Gender Justice. South African News Agency (2018) 'Gender Based Violence on the Rise', available at: https://www. sanews.gov.za/south-africa/gender-based-violen ce-rise, site accessed September 4, 2019.

Stacey M, Konstant T, Rangasami J, Stewart M and Mans G (2013) 'Sex workers in South Africa: A rapid size estimation study', available at: http://www.sweat.org.za/wpcontent/uploads/2016/02/Sex-Workers-Size-Estim ation-Study-2013.pdf, site accessed September 4, 2019.

$S$ v Zwelethu Harold Joseph Mthethwa, Western Cape High Court, 16 March 2017 (Unreported).

United Nations Office on Drugs and Crime (2018) 'Global Study on Homicide: Gender-Related Killing of Women and Girls', available at: https:// www.unodc.org/documents/data-and-analysis/ GSH2018/GSH18_Gender-related_killing_of_ women_and_girls.pdf, site accessed September 4, 2019.

Ward H, Day S and Weber J (1999) 'Risky business: Health and safety in the sex industry over a 9year period', in Sexually Transmitted Infections, $75,5,340-343$.

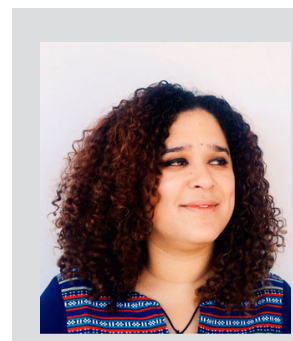

CHERITH SANGER holds an LLB degree from the University of the Western Cape (UWC) and an LLM with a specialisation in Public Interest Law and Policy with honours from the University of California, Los Angeles. She was admitted as an attorney in 2007 and since then has conducted impact litigation and legal advocacy to advance women's rights and gender equality. In recent years, she worked for the Sex Workers Education and Advocacy Taskforce and provided legal services to gender, health and human rights civil society organisations. She lectures in the Department of Criminal Justice \& Procedure in UWC's Law Faculty, and is currently also reading for a $\mathrm{PhD}$ in the area of police corruption and sex work. Email: csanger@uwc.ac.za 